\title{
Soil physicochemical (colloidal) properties affected by ozonated water and organic fertilization
}

\author{
Maryam Tahamolkonan ${ }^{1} \cdot$ Ahmad Mohammadi Ghehsareh ${ }^{1} \cdot$ Mahmoud Kalbasi Ashtari $^{1} \cdot$ Naser Honarjoo $^{1}$
}

Received: 1 March 2021 / Revised: 29 May 2021 / Accepted: 3 June 2021

(c) The Author(s), under exclusive licence to Springer-Verlag GmbH Germany, part of Springer Nature 2021

\begin{abstract}
More has to be investigated on the use of ozonated water (O3) for the improvement of growth medium properties. Accordingly, the objective was to examine the effects of $\mathrm{O} 3$ (control, $0.5,1.0$, and $2.0 \mathrm{mg} \mathrm{L}^{1}$ ) on soil physicochemical (colloidal) properties using organic fertilization (manure), under non-planted or planted conditions. Different soil physicochemical (colloidal) properties including soil available water (SAW), aggregate stability, soil porosity, pH, salinity (EC), organic carbon (SOC), $\mathrm{CaCO}_{3}$, and cation exchange capacity (CEC) were determined. The experimental treatments and their interactions significantly $(P \leq 0.05)$ affected soil physicochemical properties including SAW $(4.17-10.98 \%)$, aggregate stability and porosity $(7.77-57.37 \%)$, SOC $(0.15-2.09 \%)$, and CEC $(17.68-42.75 \mathrm{Cmol}(+) / \mathrm{kg})$. Interestingly, the single use of O3 or in combination with manure significantly decreased EC. Although O3 significantly decreased SOC in non-planted soils, it significantly increased SOC in planted soils. O3 may enhance soil physicochemical (colloidal) properties, and if combined with manure in a planted soil, such positive effects may be further enhanced.
\end{abstract}

Keywords Aggregate stability $\cdot$ Soil available water $\cdot$ Cation exchange capacity $\cdot$ Organic carbon $\cdot$ Ozonated water

\section{Introduction}

The healthy and sustainable production of agricultural crops is essential for feeding the world increasing population. Different methods and techniques have been so far used to increase agricultural and horticultural products $[1,2]$ including organic farming, biological fertilization, plant growth regulators, and ozonated water $[38,47]$. The technique of ozonated water is among the newest ones and has been used for different purposes including the disinfection of waste and polluted waters. Ozone is produced in the atmosphere by the catalysis of ozone molecule into oxygen atoms, which then react with oxygen $\left(\mathrm{O}_{2}\right)$ molecules and produce ozone $[4,35,37,50]$.

Due to the high oxidizing potential of ozone molecules, they can significantly influence soil properties. For example, ozone can disinfect soil medium and mineralize organic matter available in different parts of the soil including soil colloids $[8,11]$. Accordingly, ozone may enhance soil fertility

Ahmad Mohammadi Ghehsareh

amohammadi@khuisf.ac.ir

1 Department of Soil Science, College of Agriculture, Isfahan (Khorasgan) Branch, Islamic Azad University, Isfahan, Iran affecting plant growth and microbial activities. However, as an oxidizing molecule, ozone may significantly mineralize soil organic matter resulting in the degradation of soil structure. Accordingly, manure was also tested as an experimental treatment to test if it can alleviate the negative effects of ozone on soil properties.

Due to the non-stability of ozone molecule, it is produced at the place of consumption. Ozonated water in the present research was produced using an ozone instrument generator, which is able to turn $\mathrm{O} 2$ molecule into oxygen atoms at high voltage, and in combination with $\mathrm{O} 2$ produce $\mathrm{O} 3$. The solubility of $\mathrm{O} 3$ in water is not high, so using a diffuser its solubility was optimized [47]. One of the important factors, which determines ozone solubility, is water $\mathrm{pH}$. Some ozone molecules are decomposed with increasing water $\mathrm{pH}$ (due to the presence of $\mathrm{OH}^{-}$), which is enhanced by organic compounds affecting ozone half-life. For example, in the typical drinking water, ozone half-life is between 1 and $20 \mathrm{~min}$. However, carbonate ion can prevent the degradation of ozone in water (Hoigné, 1988).

Although there is not much research on the effects of ozonated water $(\mathrm{O} 3)$ on plant growth, a few experiments have so for indicated the positive effects of $\mathrm{O} 3$ on plant growth under different conditions including stress. For example, 
Peykanpour et al. [39] investigated the effects of O3 on cucumber (Cucumis sativus L.) growth under salt stress. They found that the $\mathrm{O} 3$ treatment $\left(0.5\right.$ and $\left.1.0 \mathrm{mgL}^{-1}\right)$ could improve cucumber growth under the stress by significantly increasing plant fresh and dry weights, fruit yield, and plant leaf area.

In another research, Graham et al. [16] investigated the effects of $\mathrm{O} 3$ on the growth of tomato (Licopersicon esculentum L.) and similarly found that ozone at $3.0 \mathrm{mgL}^{-1}$ significantly increased tomato fresh weight and leaf area, and significantly decreased algal growth. Accordingly, such researchers indicated that the proper concentration of ozone (oxygen) in water can improve plant growth by increasing plant metabolism. Peng et al. [38] examined the effects of diluted sludge treated with ozone, on lettuce growth ( $\mathrm{Lac}$ tuca sativa L.) and found although this treatment was not significant on lettuce growth and production, it significantly improved lettuce biochemical properties by increasing chlorophyll, ascorbic acid, and soluble sugar, and by decreasing plant nitrate.

Graham et al. [16] speculated that because of a strong oxidizing potential [19], O3 can also affect plant growth, by increasing the availability of soil nutrients for plant and soil microbes. The other interesting effect of ozonation is on the disinfection of microbes including fungi, bacteria, and viruses $[12,36]$. For example, even the potential use of ozone for controlling the pandemic Coronavirus has been suggested and tested [48]. The mineralizing effects of ozone on soil organic matter can be through the production of $\mathrm{OH}$ radicals resulted by the catalytic decomposition of ozone [11, 41]. However, organic fertilization (manure) can also alleviate the negative effects of ozone on soil physicochemical properties by acting as a substrate for ozone, and reducing the oxidization of soil organic matter by ozone.

Plant presence can also importantly affect soil physicochemical and microbial properties, mainly due to the effects of rhizosphere [42]. However, to our knowledge, there is not any data on the combined effects of $\mathrm{O} 3$, plant presence, and manure affecting soil physicochemical properties. Tahamolkonan et al. [47] just indicated the use of $\mathrm{O} 3$ and organic fertilization (manure) can improve tomato growth and fruit quality by affecting plant biochemical properties including total soluble solids, total sugar, chlorophyll contents, and vitamin $\mathrm{C}$ (ascorbic acid).

Although according to the abovementioned details, the direct effects of $\mathrm{O} 3$ on plant growth and production have been researched, to our knowledge, there is little data on O3 affecting soil physicochemical (colloidal) properties. Organic fertilization such as manure can also enhance soil physicochemical (colloidal) properties. However, the combined effects of manure and $\mathrm{O} 3$, in a planted growth medium, have yet to be investigated. It has been proposed in this research that although one of the main reasons for the positive effects of ozonated water on plant growth is the increased availability of oxygen for plant use, it may also improve plant growth by enhancing the growth medium (soil) properties.

With respect to the abovementioned details, one important question, which has been rarely investigated, and requires more investigation, is the effects of $\mathrm{O} 3$ on soil physicochemical (colloidal) properties. It is also pertinent to provide an organic medium such as manure to determine if different soil properties are differently affected by O3, due to the increased availability of nutrient in a non- or planted-soil.

\section{Materials and methods}

\subsection{Experimental site}

The experiment was conducted in the Research Greenhouse of Islamic Azad University (Isfahan Branch), Isfahan, Iran, from the November of 2014 to the June of 2015, at the eastern longitude and northern latitude of $51^{\circ}$ and $37^{\prime}$ and $35^{\circ}$ and $47^{\prime}$, respectively, $1549 \mathrm{~m}$ above the sea level. The area of the Research Greenhouse is equal to $270 \mathrm{~m}^{2}$, covered with a poly ethylene layer with $4.5 \%$ of an ultraviolet (UV) micron layer, resistant to UV, with an arch-like structure and three halls, each $45 \mathrm{~m}$ big. The pots were irrigated with hand; the greenhouse has a heating (heater) and cooling (cooler) system $\left(15-27^{\circ} \mathrm{C}\right)$, a thermometer, humidity meter, and a gate on the ceiling to aerate the greenhouse (Fig. 1).

\subsection{Ozonation}

The following concentrations of ozonated water (O3) were tested in this experiment: control (0), 0.5, 1 , and $2 \mathrm{mg} \mathrm{L}^{-1}$ produced using the following ozone generator (brand: Parto Parsezesh, Iran) [47]. The capacity of ozone generator is $70 \mathrm{mg}$ ozone per minute, measuring $180 \times 360 \times 420 \mathrm{~mm}$, and weighing $11 \mathrm{~kg}$. The voltage is $220 \mathrm{~V}$, with a fan, a resistant gas tube, a controlling system to avoid water entering the generator, a compressor to supply air for the generator, and a one-way ozone valve to avoid reentering ozone.

It is notable the concentrations are ozone concertation in water, which were used to dilute the nutrient's stock solution used to irrigate the plants. The oxygen (with the purity of $21 \%$ ) was entered into the generator by an internal valve and it was circulated between the two electrodes, isolated by a dielectric. At high voltage, the electrodes catalyze the oxygen molecules into two oxygen atoms, which react with an oxygen molecule, resulting in the production of ozone molecules, directed out of the instrument using an external valve. Since ozone is not much soluble in water $\left(14 \mathrm{mM}\right.$. $\mathrm{L}^{-1}$ at $20{ }^{\circ} \mathrm{C}$ ), using a diffuser the process of ozone solubilization 

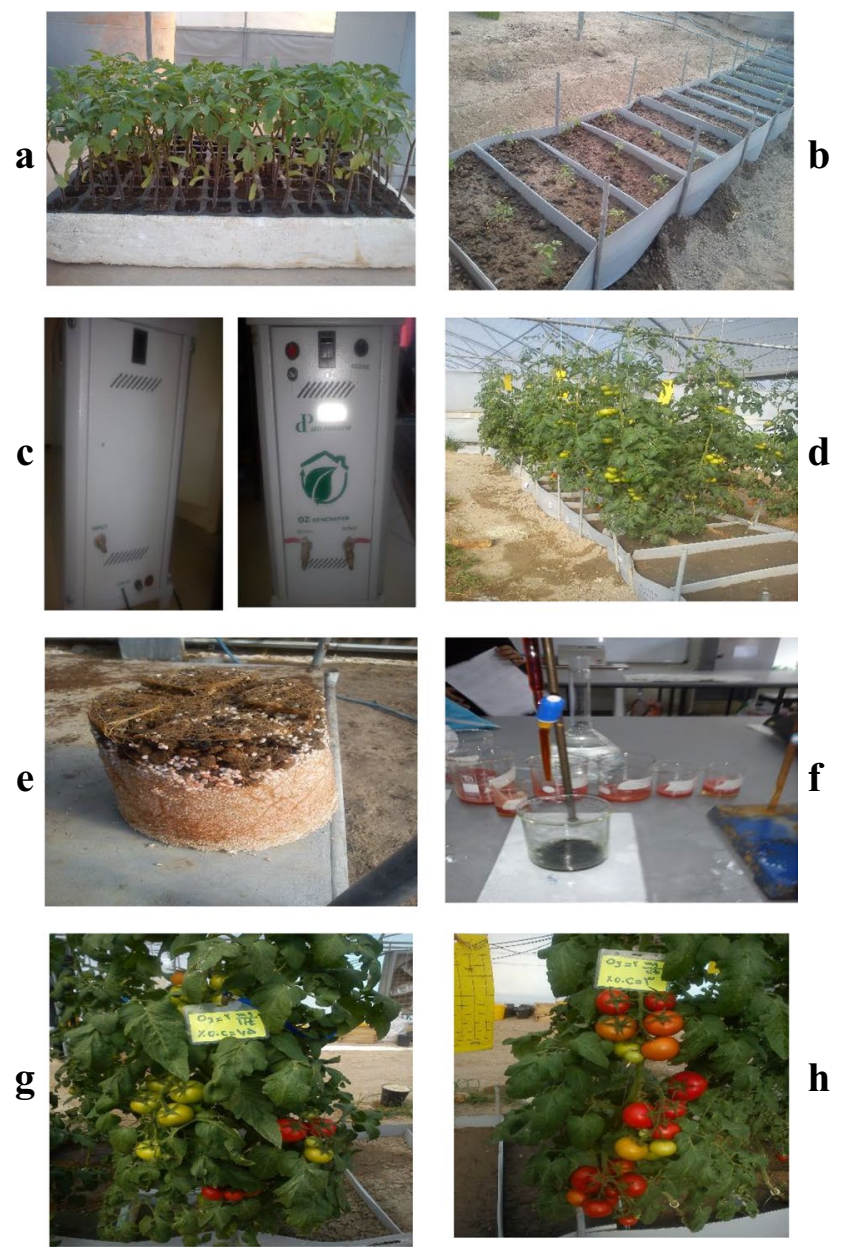

Fig. 1 Different stages of the experiment including: a seedling growth, $\mathbf{b}$ transplantation of seedlings, $\mathbf{c}$ the process of ozonating water, $\mathbf{d}$ growth of tomato plants in the greenhouse, e organic fertilized soil with manure, $\mathbf{f}$ soil measurements, $\mathbf{g}$ tomato plants treated with control fertilization (without manure) and Oz3, and $\mathbf{h}$ tomato plants treated with organic fertilization (manure) and $\mathrm{Oz} 3$

was optimized; the diffuser was connected to the external valve by a tube. The diffuser was made of sand and silt, with the sides of $20 \times 20 \times 20 \mathrm{~mm}$, and ozone was diffused from bottom to top.

The final concertation of ozone in water was determined using ozone test kit. The medium used for the experiment consisted of a control soil and the combination of a control soil and organic medium (ship manure). The pots containing the experimental medium were non-planted (control) and planted.

The gas (ozone) flow rate by the instrument is $70 \mathrm{mg} \mathrm{min}^{-1}$, and because the solubility of ozone in water (at $20{ }^{\circ} \mathrm{C}$ ) is $672 \mathrm{mg} \mathrm{L}^{-1}(14 \mathrm{~mol})$, the gas flow rate at $0.5,1$, and $2 \mathrm{~min}$, injected into $1 \mathrm{~L}$ of tab water, resulted in $\mathrm{O} 3$ with the ozone concentrations of $0.5,1.0$, and $2.0 \mathrm{mg} \mathrm{L}^{-1}$. The stock solution containing the nutrients was immediately diluted with the prepared O3 and was used to irrigate the pots. Due to the process of sterilization and disinfection, tab water contains negligible amount of organic matter and dissolve inorganic. The plants were treated with the $\mathrm{O} 3$ treatment for five months. The plants were irrigated with $\mathrm{O} 3$ when the pot moisture was near the wilting point. Each pot contained $3 \mathrm{~kg}$ of soil and was irrigated with $2 \mathrm{~L}$ of O3. The transplantation of seedlings was conducted at three-leaf growth stage. The seedlings were first irrigated with tab water, and after the establishment, they were irrigated with O3. All the measured parameters were determined at harvest.

\subsection{Experimental treatments}

The experiment was a split-split plot in which the soil treatments were devoted to the main plots, planting to the subplots, and $\mathrm{O} 3$ to the sub-sub plots. The experiment consisted of 16 treatments (with three replicates) including the pots containing control soil (S1) or control + organic fertilized soil (manure with $56 \%$ moisture, at $1.5 \mathrm{~kg}$ per plot) (S2), non-planted (P1) and planted (P2), and irrigated with $\mathrm{O} 3$ at control (Oz1), $0.5(\mathrm{Oz} 2), 1.0(\mathrm{Oz} 3)$, and $2.0(\mathrm{Oz} 4) \mathrm{mgL}^{-1}$. The plots measuring $80 \times 40 \times 40 \mathrm{~cm}(\mathrm{~L} \times \mathrm{W} \times \mathrm{H})$ were transplanted with tomato seedlings at the V3 (three-leaf growth) stage (27/10/2014). The chemical properties of manure were according to the following: $\mathrm{pH}: 7.8, \mathrm{EC}: 18.6, \mathrm{OC}: 15.9 \%$, $\mathrm{N}: 2.26 \%$, P: $1.23 \%, \mathrm{~K}: 2.3 \%$, Ca: $2.1 \%$. The control soil used for the experiment was a clay loam [14], with the $\mathrm{pH}$ of 7.6, salinity of $904 \mu \mathrm{S} \mathrm{cm}^{-1}$ [43], organic matter of $1.5 \%$ [32], and bulk density of $1.3 \mathrm{~g} \mathrm{~cm}^{-3}$ [28].

\subsection{Measurements}

Different soil physicochemical properties including the stability of soil aggregates, mean weight diameter (MWD), geometry mean diameter (GMD), soil texture, soil available water (SAW), salinity (EC) and acidity $(\mathrm{pH})$ of a saturated paste, organic carbon (SOC), cation exchange capacity (CEC), $\mathrm{CaCO}_{3}$, and morphological properties of the experimental soil were determined.

\subsubsection{Stability of soil aggregates}

The stability of soil aggregates was measured using the wet sieving method [3]. The soil samples were first air-dried, sieved through a 4.75-mm mesh (\#4), and moistened using a plastic tray. The soil aggregates were then meshed by the sizes of $2.0,1.0,0.5,0.25$, and $0.05 \mathrm{~mm}$ (30 rounds per minute) for $5 \mathrm{~min}$. The meshes were then removed from the water, and the remaining aggregates on each mesh were washed and finally dried at $65{ }^{\circ} \mathrm{C}$. Due to the presence of sand, the stability of aggregates had to be adjusted. Accordingly, the aggregates were spread on the same sizes of mesh, oven dried, weighed, and deducted from the initial weight 
of the aggregates on each mesh, and finally, the aggregates were precisely determined. The two parameters of MWD and GMD were also calculated using the following formulas.

$M W D=\sum_{i=1}^{n} \bar{X}_{i} W_{i}$

In which " $X_{\mathrm{i}}$ " is the mean weight diameter on each mesh with the size of " $i$ " (the mean diameter of the meshes), $n$ is the number of meshes, and $W_{\mathrm{i}}$ is the ratio of each aggregate weight to the total weight of the soil excluding the weight of sand.

GMD was calculated using the following formula:

$$
G M D=\exp \left(\frac{\sum_{i=1}^{n} W i \log \bar{X} i}{\sum_{i=1}^{n} W i}\right)
$$

\subsubsection{Soil available water}

Soil available water (SAW), defined as the difference between the maximum amount of water (field capacity), held by soil and wilting point, which there is not any water available for plant use, was determined using the following method (Cassel, D.K. and Nielsen, D.R., 1986). The metal tubes containing the soil samples were inserted into a pressure-plate instrument, and the moisture of soil samples was measured at the suctions of 0.3 and 15 bars. Accordingly, to saturate the tubes, they were inserted into water for $24 \mathrm{~h}$, and their moisture was determined using the instrument.

\subsubsection{Salinity and acidity}

Using $300 \mathrm{~g}$ of meshed soil, saturated with distilled water for $24 \mathrm{~h}$, the samples were extracted with Buckner Funnel (Model B-55), and then, the salinity (EC) of soil samples was determined using a conductivity meter (Model 712) at $25^{\circ} \mathrm{C}$. The acidity of the saturated paste was also determined using a pH meter (Metrohm, model 827) (Klute, 1986).

\subsubsection{SOC}

Using the wet oxidation method (potassium bichromate and sulfuric acid), and by the reversible titration with ammonium ferrous sulfate, SOC was determined [49].

\subsubsection{CEC}

Using the sodium acetate method, soil CEC was determined according to the following stages: (1) saturation with sodium acetate, (2) rinsing the cations with ethanol 95\%, (3) exchanging sodium $(\mathrm{Na}+)$ by ammonium $\left(\mathrm{NH}_{4}{ }^{+}\right)$using sodium acetate, and (4) measuring $\mathrm{Na}+$ using flame photometer, which was calculated on the basis of meq/100 $\mathrm{g}$ soil.

Accordingly, $2.5 \mathrm{~g}$ air-dried soil was poured into the centrifuge tubes, treated with $25 \mathrm{~mL}$ sodium acetate $1 \mathrm{~N}$ and shaken (2500 g) for $5 \mathrm{~min}$, and the supernatant was poured away (repeated twice). The same method was also used by white ethanol, and at the third time, the EC of supernatant was measured to make sure its salinity is less than $40 \mu \mathrm{S} \mathrm{cm}^{-1}$; if it was higher, more rinsing was done. In the next stage, each sample was treated with $25 \mathrm{~mL}$ sodium acetate $1 \mathrm{~N}$, just similar to the abovementioned details (repeated twice); however, this time the supernatant was collected and poured into a $50-\mathrm{ml}$ volumetric flask, which was brought up to volume to measure $\mathrm{Na}+$ concentration using the flame photometer [44].

\subsection{6 $\mathrm{CaCO}_{3}$}

Soil $\mathrm{CaCO}_{3}$ was measured according to the following: $1 \mathrm{~g}$ air-dried soil was meshed, and poured into a $250-\mathrm{ml}$ volumetric flask, and was treated and shaken well with $20 \mathrm{ml}$ $\mathrm{HCl} 1 \mathrm{~N}$. The samples were cool down and treated with $5 \mathrm{~mL}$ phenolphthalein indicator and $\mathrm{NaOH} 1 \mathrm{~N}$ until the appearance of purple color.

\subsubsection{Micromorphology of soil samples (quantitative study of soil porosity)}

Using the following method, the quantitative study of soil porosity in the thin slices of soil samples was conducted. The undisturbed soil samples were air-dried and were saturated using polyester resin containing $60 \%$ resin, $40 \%$ acetone (diluter), 14 drops of catalyst, and seven drops of cobalt. The samples were gradually saturated under vacuum with the addition of resin; it took 6 weeks, for hardening the samples [34]. The sections of the samples were observed using the polarizan microscope, and from each section, one picture was taken under normal polarizan, and was investigated using the related software to determine the soil porosity of $<2,2-10$, and $>10 \mu \mathrm{m}[13]$.

\subsection{Statistical analyses}

Data were subjected to analysis of variance using SAS. Means were compared by least significant difference (LSD) at $P \leq 0.05$.

\section{Results}

\subsection{Analysis of variance}

According to the analysis of variance, none of the experimental treatments significantly affected soil $\mathrm{pH}$. However, 
the single and the interaction effects of the experiential treatments were significant on soil EC. Interestingly, organic fertilization (manure) did not affect SOC, which was significantly affected by the other experimental treatments including plantation and $\mathrm{O} 3$ and their interaction. The other soil properties including $\mathrm{CaCO}_{3}$, SAW, and CEC were also significantly affected by the single and interaction effects of the experimental treatments (Table 1).

\subsection{SAW}

O3 significantly increased SAW, and with increasing ozone concentration, such effects became clearer as at the highest level of ozone concentration, under different experimental treatments, the highest SAW was resulted. In the control soil, there was a significant difference between plantation and non-plantation treatments, at different ozone concentration (excluding Oz4). However, when combining organic fertilization (manure) with the control soil, the effects of plantation became apparent as SAW significantly increased in the planted soil, related to the non-planted soil. The least SAW $(4.17 \%)$ was resulted by S2P2Oz1 (fertilized soil, planted and not ozonated), and the highest ones (10.98 and 10.13\%) were related to S1P2Oz4 (fertilized soil, not planted and ozonated at $2 \mathrm{mg} \mathrm{L}^{-1}$ ) and S1P1Oz3 (control soil, not planted and ozonated at $1.5 \mathrm{mg} \mathrm{L}^{-1}$ ), respectively (Table 2).

\section{$3.3 \mathrm{pH}$}

There were not any significant effects of the experimental treatments on soil $\mathrm{pH}$ ranging from 8.04 (S2P2Oz4, fertilized soil, planted and ozonated at $2 \mathrm{mg} \mathrm{L}^{-1}$ ) to 8.31 (S1P2Oz4, control soil, planted and ozonated at $2 \mathrm{mg} \mathrm{L}^{-1}$ ) (Table 2).

\subsection{Salinity}

The single and the interaction effects of the experimental treatments significantly affected soil salinity. Interestingly, in most cases, $\mathrm{O} 3$ significantly decreased soil salinity compared with control. For example, in the control and planted soil, treatments Oz3 $\left(0.59 \mathrm{dS} \mathrm{m}^{-1}\right)$ and $\mathrm{Oz} 4(0.63$ $\mathrm{dS}^{-1}$ ) significantly decreased soil salinity, compared with control $\left(0.93 \mathrm{dS} \mathrm{m}^{-1}\right)$. Similarly, in the organic fertilized planted soil, Oz2 (1.05 dS m $\left.{ }^{-1}\right)$, Oz3 $\left(0.87 \mathrm{dS} \mathrm{m}^{-1}\right)$, and $\mathrm{Oz} 4\left(0.72 \mathrm{dS} \mathrm{m}^{-1}\right)$ significantly reduced soil salinity compared with control $\left(1.33 \mathrm{dS} \mathrm{m}^{-1}\right)$. The least and the highest soil salinity levels $\left(0.59\right.$ and $\left.1.93 \mathrm{dS} \mathrm{m}^{-1}\right)$ were resulted by treatments S1P2Oz3 (control soil, planted and ozonated at $1 \mathrm{mg} \mathrm{L}^{-1}$ ) and S2P1Oz2 (fertilized soil, not planted and ozonated at $0.5 \mathrm{mg} \mathrm{L}^{-1}$ ). However, just in the case of organic, non-planted soil, O3 inreased soil salinity from $0.60 \mathrm{dS} \mathrm{m}^{-1}$ in control (Oz1) to $1.93(\mathrm{Oz} 2), 1.37$ (Oz3), and $1.04 \mathrm{dS} \mathrm{m}^{-1}(\mathrm{Oz} 4)$ (Table 2).

\subsection{Organic carbon}

In control and organic fertilized non-planted soils, $\mathrm{O} 3$ significantly decreased SOC compared with non-ozonated treatment. However, the presence of plant in the soil significantly increased SOC as treatments S1P1Oz4 (control soil, not planted and ozonated at $2 \mathrm{mg} \mathrm{L}^{-1}$ ) and S2P2Oz4 (fertilized soil, planted and ozonated at $2 \mathrm{mg} \mathrm{L}^{-1}$ ) resulted in the least $(0.51 \%)$ and the highest (2.09\%) SOC, respectively (Table 2).
Table 1 Analysis of variance indicating the effects of experimental treatments on different soil physicochemical properties

\begin{tabular}{llllllll}
\hline Sources of variation & d.f & SAW & $\mathrm{pH}$ & Salinity & $\mathrm{SOC}$ & $\mathrm{CaCO}_{3}$ & $\mathrm{CEC}$ \\
\hline B & 2 & $0.83 \mathrm{~ns}$ & $0.012 \mathrm{~ns}$ & $0.004 \mathrm{~ns}$ & $0.02 \mathrm{~ns}$ & $26.44 \mathrm{~ns}$ & $4.78 \mathrm{~ns}$ \\
O.F & 1 & $62.43^{*}$ & $0.058 \mathrm{~ns}$ & $1.45^{* *}$ & $0.08 \mathrm{~ns}$ & $198.86^{*}$ & $46.77^{*}$ \\
Error A $($ B. $\times$ O.F.) & 2 & 0.64 & 0.018 & 0.01 & 0.03 & 2.73 & 0.57 \\
P & 1 & $7.84^{*}$ & $0.001 \mathrm{~ns}$ & $0.03^{* *}$ & $0.01 \mathrm{~ns}$ & $218.03^{* *}$ & $240.31^{* *}$ \\
O.F. $\times$ P & 1 & $2.20 \mathrm{~ns}$ & $0.00005 \mathrm{~ns}$ & $0.09^{*}$ & $3.48^{* *}$ & $531.34^{* *}$ & $268.29^{* *}$ \\
Error B $($ B. $\times$ P. $\times$ O.F.) & 4 & 0.41 & 0.010 & 0.009 & 0.01 & 6.82 & 3.88 \\
Ozone & 3 & $22.44^{* *}$ & $0.005 \mathrm{~ns}$ & $0.25^{* *}$ & $0.70^{* *}$ & $25.00^{* *}$ & $330.82^{* *}$ \\
O.F. $\times$ ozone & 3 & $0.26 \mathrm{~ns}$ & $0.006 \mathrm{~ns}$ & $0.23^{* *}$ & $0.55^{* *}$ & $37.12^{* *}$ & $125.41^{* *}$ \\
P $\times$ ozone & 3 & 1.54 & $0.010 \mathrm{~ns}$ & $0.49^{* *}$ & $1.33^{* *}$ & $137.65^{* *}$ & $190.07^{* *}$ \\
O.F. $\times$ P. $\times$ ozone & 3 & 2.75 & $0.003 \mathrm{~ns}$ & $0.29^{* *}$ & $0.44^{* *}$ & $99.14^{* *}$ & $5.06 \mathrm{~ns}$ \\
Error & 24 & 0.22 & 0.008 & 0.01 & 0.01 & 2.58 & 2.98 \\
C.V. $(\%)$ & & 6.26 & 1.10 & 10.72 & 10.69 & 11.01 & 6.78 \\
\hline
\end{tabular}

d.f. degree of freedom, $S O C$ soil organic carbon, $C E C$ cation exchange capacity, $S A W$ soil available water, $B$. block, $O . F$. organic fertilization, $P$. planting, $n s$ not significant, * and ** significant at $P=0.05$ and 0.01 , respectively 
Table 2 The interaction effect of experimental treatments including ozonated water (O3), organic fertilization, and planting on different soil physicochemical properties

\begin{tabular}{|c|c|c|c|c|c|c|c|c|}
\hline Organic fertilization & Planting & $\begin{array}{l}\text { Ozone } \\
\left(\mathrm{mg} \mathrm{L}^{-1}\right)\end{array}$ & $\begin{array}{l}\text { SAW } \\
(\%)\end{array}$ & $\mathrm{pH}$ & $\begin{array}{l}\text { Salinity } \\
\left(\mathrm{dS} \mathrm{m} \mathrm{m}^{-1}\right)\end{array}$ & $\begin{array}{l}\text { SOC } \\
(\%)\end{array}$ & $\begin{array}{l}\mathrm{CaCO}_{3} \\
(\%)\end{array}$ & $\begin{array}{l}\mathrm{CEC} \\
(\mathrm{Cmol}(+) / \mathrm{kg})\end{array}$ \\
\hline \multirow[t]{8}{*}{ Control soil } & \multirow{4}{*}{ Not planted } & Control & $7.81 \pm 1.75 \mathrm{~cd}$ & $8.22 \pm 0.06$ & $0.81 \pm 0.05 \mathrm{def}$ & $1.09 \mathrm{ef}$ & $15.00 \mathrm{c}$ & $22.90 \pm 1.34 \mathrm{fg}$ \\
\hline & & 0.5 & $9.39 \pm 0.33 b$ & $8.16 \pm 0.13$ & $0.74 \pm 0.13$ fgh & $0.54 \mathrm{~g}$ & $25.83 \mathrm{a}$ & $30.72 \pm 0.95 \mathrm{~cd}$ \\
\hline & & 1 & $10.13 \pm 0.13 \mathrm{ab}$ & $8.16 \pm 0.13$ & $0.96 \pm 0.07 \mathrm{~cd}$ & $0.53 \mathrm{~g}$ & $20.00 \mathrm{~b}$ & $17.6 \pm 1.148 \mathrm{~h}$ \\
\hline & & 2 & $10.01 \pm 3.22 b$ & $8.18 \pm 0.06$ & $0.70 \pm 0.04 \mathrm{fgh}$ & $0.51 \mathrm{~g}$ & $27.50 \mathrm{a}$ & $26.96 \pm 1.64 \mathrm{e}$ \\
\hline & \multirow{4}{*}{ Planted } & Control & $6.70 \pm 0.26 \mathrm{fgh}$ & $8.18 \pm 0.06$ & $0.93 \pm 0.1 \mathrm{cde}$ & $1.11 \mathrm{ef}$ & $20.00 \mathrm{~b}$ & $19.71 \pm 2.04 \mathrm{~h}$ \\
\hline & & 0.5 & $7.02 \pm 0.16 \mathrm{dg}$ & $8.18 \pm 0.06$ & $0.77 \pm 0.03 \mathrm{efg}$ & $1.06 \mathrm{ef}$ & $12.17 \mathrm{cde}$ & $20.43 \pm 0.79 \mathrm{gh}$ \\
\hline & & 1 & $7.70 \pm 0.45 \mathrm{cde}$ & $8.20 \pm 0.06$ & $0.59 \pm 0.07 \mathrm{~h}$ & $1.43 \mathrm{c}$ & $6.25 \mathrm{f}$ & $24.06 \pm 2.50 \mathrm{f}$ \\
\hline & & 2 & $10.98 \pm 1.87 \mathrm{a}$ & $8.21 \pm 0.1$ & $0.63 \pm 0.09 \mathrm{gh}$ & $1.34 \mathrm{~cd}$ & $6.25 \mathrm{f}$ & $33.04 \pm 1.64 \mathrm{c}$ \\
\hline \multirow[t]{9}{*}{ Soil + organic fertilization } & \multirow{3}{*}{ Not planted } & Control & $5.281 \pm 0.42 \mathrm{i}$ & $8.19 \pm 0.09$ & $0.74 \pm 0.29 \mathrm{~h}$ & $1.71 \mathrm{~b}$ & $11.67 \mathrm{de}$ & $19.13 \pm 2.09 \mathrm{~h}$ \\
\hline & & 0.5 & $6.18 \pm 0.17 \mathrm{gh}$ & $8.09 \pm 0.11$ & $1.93 \pm 0.35 \mathrm{a}$ & $1.03 \mathrm{f}$ & $12.50 \mathrm{cde}$ & $18.99 \pm 1.39 \mathrm{~h}$ \\
\hline & & 1 & $6.84 \pm 0.33 \mathrm{efg}$ & $8.08 \pm 0.16$ & $1.37 \pm 0.15 b$ & $1.21 \mathrm{de}$ & $15.00 \mathrm{c}$ & $20.29 \pm 1.84 \mathrm{gh}$ \\
\hline & \multirow{5}{*}{ Planted } & 2 & $8.21 \pm 0.44 c$ & $8.09 \pm 0.01$ & $1.04 \pm 0.20 \mathrm{c}$ & $1.18 \mathrm{def}$ & $6.27 \mathrm{f}$ & $28.84 \pm 1.84 \mathrm{de}$ \\
\hline & & Control & $4.17 \pm 0.89 \mathrm{j}$ & $8.12 \pm 0.09$ & $1.33 \pm 0.31 b$ & $0.25 \mathrm{~h}$ & $18.33 \mathrm{~b}$ & $22.61 \pm 1.37 \mathrm{fg}$ \\
\hline & & 0.5 & $5.94 \pm 0.57 \mathrm{hi}$ & $8.12 \pm 0.10$ & $1.05 \pm 0.15 \mathrm{c}$ & $0.15 \mathrm{~h}$ & $10.83 \mathrm{e}$ & $20.29 \pm 1.60 \mathrm{gh}$ \\
\hline & & 1 & $7.13 \pm 0.23 \mathrm{def}$ & $8.20 \pm 0.03$ & $0.87 \pm 0.14 \mathrm{def}$ & $0.62 \mathrm{~g}$ & $11.67 \mathrm{de}$ & $38.41 \pm 2.50 \mathrm{~b}$ \\
\hline & & 2 & $7.75 \pm 0.41 \mathrm{~cd}$ & $8.26 \pm 0.06$ & $0.72 \pm 0.03$ fgh & $2.09 \mathrm{a}$ & $14.17 \mathrm{~cd}$ & $42.75 \mathrm{a}$ \\
\hline & LSD & & & 0.16 & 0.17 & 0.19 & 2.96 & 2.86 \\
\hline
\end{tabular}

$S A W$ soil available water, $S O C$ soil organic carbon, $C E C$ cation exchange capacity. Means followed by the same letter are not significantly different at $P=0.05$ using least significant difference (LSD) test

\section{$3.6 \mathrm{CaCO}_{3}$}

$\mathrm{O} 3$ significantly increased $\mathrm{CaCO}_{3}$ in non-planted soil; however, in planted soils, $\mathrm{CaCO}_{3}$ significantly decreased with increasing ozone concertation. The least $(6.25 \%)$ and the highest percentages $(27.50 \%)$ of $\mathrm{CaCO}_{3}$ were resulted by treatments $\mathrm{S} 1 \mathrm{P} 2 \mathrm{Oz} 4$ (control soil, not planted and ozonated at $2 \mathrm{mg} \mathrm{L}^{-1}$ ) and S1P1Oz4 (control soil, not planted and ozonated at $2 \mathrm{mg} \mathrm{L}^{-1}$ ), respectively (Table 2).

\subsection{Cation exchange capacity}

According to the results, O3, especially $\mathrm{Oz} 3$ and $\mathrm{Oz} 4$, significantly increased cation exchange capacity (CEC) under different treatments. Planting, especially in the organic fertilized soil, significantly increased CEC. The least (17.68 $\mathrm{cmol}(+) / \mathrm{kg})$ and the highest $(42.75 \mathrm{cmol}(+) / \mathrm{kg}) \mathrm{CEC}$ were resulted by S1P1Oz3 (control soil, not planted and ozonated at $1 \mathrm{mg} \mathrm{L}^{-1}$ ) and S2P2Oz4 (fertilized soil, planted and ozonated at $2 \mathrm{mg} \mathrm{L}^{-1}$ ), respectively (Table 2).

\subsection{Soil aggregates}

Analysis of variance indicated the significant effects of planting, $\mathrm{O} 3$, and their interaction with organic fertilized soil on MWD. However, GWD was significantly affected by all the experimental treatments and their interactions. With increasing the size of soil porosity, the significant effects of the experimental treatments and their interactions became clearer as at $>10 \mu \mathrm{m}$, all the experimental treatments and some of their interactions significantly affected soil porosity with maximum values in the range of 10.1-13.1\% (Table 3).

\subsection{MWD and GMD}

The results indicated that $\mathrm{O} 3$ significantly increased MWD in P1 treatments as treatments S1P1Oz2 (control soil, not planted and ozonated at $0.5 \mathrm{mg} \mathrm{L}^{-1}$ ) and S2P1Oz3 (fertilized soil, not planted and ozonated at $1 \mathrm{mg} \mathrm{L}^{-1}$ ) resulted in the highest $(0.847$ and $0.870 \mathrm{~mm}) \mathrm{MWD}$ values. However, the least MWD values $(0.593$ and $0.540 \mathrm{~mm})$ were related to the $\mathrm{P} 2$ treatments by $\mathrm{S} 1 \mathrm{P} 2 \mathrm{Oz} 4$ (control soil, planted and ozonated at $2 \mathrm{mg} \mathrm{L}^{-1}$ ) and S2P2Oz3 (fertilized soil, planted and ozonated at $\left.1 \mathrm{mg} \mathrm{L}^{-1}\right)$. Similarly, the GMD values were also the highest under P1 treatments, and S1P1Oz2 (control soil, not planted and ozonated at $0.5 \mathrm{mg} \mathrm{L}^{-1}$ ) and S2P1Oz3 (fertilized soil, not planted and ozonated at $1 \mathrm{mg} \mathrm{L}^{-1}$ ) treatments had the highest $(0.820$ and $0.797 \mathrm{~mm})$ GMD values (Table 4).

According to the results, $\mathrm{O} 3$ significantly increased soil porosity of $2 \mu \mathrm{m}$ as treatment S1P1Oz4 (control soil, not planted and ozonated at $2 \mathrm{mg} \mathrm{L}^{-1}$ ) resulted in the highest value (57.37\%), significantly higher than the control treatment $(48.43 \%)$. There was not a clear trend 
Table 3 Analysis of variance indicating the effects of organic fertilization, ozonated water, and their interaction on MWD, GMD, and soil porosity in each aggregate size $(\mu \mathrm{m})$ including $<2,2-10$, and $10>10$

\begin{tabular}{|c|c|c|c|c|c|c|}
\hline \multicolumn{7}{|l|}{ Mean of squares } \\
\hline Sources of variation & d.f & MWD (mm) & GMD (mm) & $<2(\mathrm{~mm})$ & $2-10(\mu \mathrm{m})$ & $>10(\mu \mathrm{m})$ \\
\hline B & 2 & 0.003 & $0.0004 * *$ & $70.60 * *$ & 0.58 & $0.62 *$ \\
\hline O.F & 1 & 0.008 & $0.002 * *$ & 2.00 & 57.64 & $12.00 * *$ \\
\hline Error a (B.×O.F.) & 2 & 0.0006 & 0.000002 & 0.50 & 6.28 & 0.008 \\
\hline $\mathrm{P}$ & 1 & $0.314 * *$ & $0.070 * *$ & 2.00 & $23.80 * *$ & $21.07 * *$ \\
\hline O.F. $\times \mathrm{P}$ & 1 & $0.003^{*}$ & 0.000002 & 2.00 & $7.36^{*}$ & $0.70^{*}$ \\
\hline Error b $(\mathrm{B} . \times$ P. $\times$ O.F. $)$ & 4 & 0.0003 & 0.0002 & 0.50 & 0.74 & 0.04 \\
\hline Ozone & 3 & $0.007 * *$ & $0.003 * *$ & $322.88 * *$ & 3.03 & $17.73 * *$ \\
\hline O.F.xozone & 3 & $0.016 * *$ & $0.003 * *$ & 2.00 & $4.48^{*}$ & $1.36^{*}$ \\
\hline P.oxzone & 3 & $0.012 * *$ & 0.0007 & 2.00 & 3.19 & 0.44 \\
\hline O.F.XP.×ozone & 3 & $0.021 * *$ & $0.006 * *$ & 2.00 & 2.28 & 1.15 \\
\hline Error & 24 & 0.001 & 0.0002 & 24 & 1.46 & 0.33 \\
\hline C.V & & 4.93 & 2.15 & 2.79 & 3.71 & 5.73 \\
\hline
\end{tabular}

d.f. degree of freedom, $M W D$ mean weight diameter, $G M D$ geometric mean diameter, $B$. block, O.F . organic fertilization, $P$. planting, *,**: significant at $P=0.05$ and 0.01 , respectively of soil, planting, and $\mathrm{O} 3$ on the soil porosity of $2-10 \mu \mathrm{m}$. However, in the soil porosity of $>10 \mu \mathrm{m}$ with increasing ozone concentration, soil porosity significantly increased. For example, in the treatments $\mathrm{S} 1 \mathrm{P} 1 \mathrm{Oz}$, the highest value $(10.10 \%)$ of $>10 \mu \mathrm{m}$ was related to treatment S1P1Oz4 (control soil, not planted and ozonated at $2 \mathrm{mg} \mathrm{L}^{-1}$ ) significantly higher than the control treatment (8.43\%); in the treatments $\mathrm{S} 2 \mathrm{P} 2 \mathrm{zO}$, the highest value (13.13\%) of $>10 \mu \mathrm{m}$ was resulted by S2P2Oz4 (fertilized soil, planted and ozonated at $2 \mathrm{mg} \mathrm{L}^{-1}$ ) significantly different from control (9.43\%) (Table 4).

\section{Discussion}

It is important to use modern techniques, which may contribute to the health of the society and increase the production of food for the world increasing population. The improvement

Table 4 The interaction effect of experimental treatments including organic fertilization, planting, and ozonated water on MWD, GMD, and soil porosity $(\%)$ in each aggregate size $(\mu \mathrm{m})$ including $<2,2-10$, and $>10$

\begin{tabular}{|c|c|c|c|c|c|c|c|}
\hline Organic fertilization & Planting & Ozone (mg/L) & MWD (mm) & GMD (mm) & $<2(\mu \mathrm{m})$ & $2-10(\mu \mathrm{m})$ & $>10(\mu \mathrm{m})$ \\
\hline \multirow[t]{8}{*}{ Control soil } & \multirow[t]{5}{*}{ Not planted } & Control & $0.757 \pm 0.01 b$ & $0.787 \pm 0.01 b c$ & $48.43 \mathrm{c}$ & $35.23 \mathrm{ab}$ & 8.43hi \\
\hline & & 0.5 & $0.847 \pm 0.01 \mathrm{a}$ & $0.820 \pm 0.01 \mathrm{a}$ & $44.73 d$ & $34.07 \mathrm{abc}$ & $7.77 \mathrm{i}$ \\
\hline & & 1 & $0.730 \pm 0.05 b$ & $0.730 \pm 0.02 \mathrm{e}$ & $53.10 \mathrm{~b}$ & $33.37 \mathrm{bcd}$ & $8.80 \mathrm{gh}$ \\
\hline & & 2 & $0.753 \pm 0.05 b$ & $0.750 \pm 0.02 \mathrm{de}$ & $57.37 \mathrm{a}$ & $33.33 \mathrm{~b}-\mathrm{e}$ & $10.10 \mathrm{ef}$ \\
\hline & & Control & $0.573 \pm 0.05 \mathrm{de}$ & $0.690 \pm 0.03 \mathrm{fg}$ & N.A & $33.53 \mathrm{a}-\mathrm{d}$ & 10.10ef \\
\hline & \multirow[t]{3}{*}{ Planted } & 0.5 & $0.610 \pm 0.01 \mathrm{~d}$ & $0.690 \pm 0.03 \mathrm{fg}$ & N.A & $35.57 \mathrm{a}$ & $8.90 \mathrm{gh}$ \\
\hline & & 1 & $0.600 \pm 0.01 \mathrm{~d}$ & $0.703 \pm 0.01 \mathrm{f}$ & N.A & $32.93 \mathrm{cde}$ & $11.20 \mathrm{bc}$ \\
\hline & & 2 & $0.593 \pm 0.02 \mathrm{de}$ & $0.700 \pm 0.02 \mathrm{f}$ & N.A & $31.47 \mathrm{def}$ & $11.17 \mathrm{bcd}$ \\
\hline \multirow[t]{9}{*}{ Soil + organic fertilization } & \multirow[t]{5}{*}{ Not planted } & Control & $0.730 \pm 0.01 b$ & $0.767 \pm 0.01 \mathrm{~cd}$ & N.A & $32.63 \mathrm{cde}$ & $9.43 \mathrm{fg}$ \\
\hline & & 0.5 & $0.717 \pm 0.06 b c$ & $0.730 \pm 0.02 \mathrm{e}$ & N.A & $32.60 \mathrm{cde}$ & 8.33hi \\
\hline & & 1 & $0.870 \pm 0.07 \mathrm{a}$ & $0.797 \pm 0.03 \mathrm{ab}$ & N.A & $31.87 \mathrm{def}$ & $10.53 \mathrm{cde}$ \\
\hline & & 2 & $0.673 \pm 0.01 \mathrm{c}$ & $0.747 \pm 0.01 \mathrm{de}$ & N.A & $33.27 \mathrm{~b}-\mathrm{e}$ & $11.77 \mathrm{~b}$ \\
\hline & & Control & $0.737 \pm 0.05 b$ & $0.747 \pm 0.01 \mathrm{de}$ & N.A & $30.40 \mathrm{f}$ & $9.43 \mathrm{fg}$ \\
\hline & \multirow[t]{3}{*}{ Planted } & 0.5 & $0.570 \pm 0.03 \mathrm{de}$ & $0.673 \pm 0.01 \mathrm{gh}$ & N.A & $30.03 \mathrm{f}$ & 10.30def \\
\hline & & 1 & $0.540 \pm 0.02 \mathrm{e}$ & $0.657 \pm 0.01 \mathrm{~h}$ & N.A & $31.20 \mathrm{ef}$ & $11.53 b$ \\
\hline & & 2 & $0.560 \pm 0.03 \mathrm{de}$ & $0.657 \pm 0.01 \mathrm{~h}$ & N.A & $29.97 \mathrm{f}$ & $13.13 \mathrm{a}$ \\
\hline & LSD & & 0.052 & 0.025 & 2.17 & 2.16 & 0.87 \\
\hline
\end{tabular}

$M W D$ mean weight diameter, GMD geometric mean diameter. Means followed by the same letter are not significantly different at $P=0.05$ using least significant difference (LSD) test. N.A. not available 
of growth media for the production of agricultural and horticultural corps is an important aspect in this respect. In the present research, the effects of $\mathrm{O} 3$ in a mineral soil singly or treated with organic fertilization (manure) non-planted and planted on soil physicochemical properties were investigated. Interestingly, the results indicated $\mathrm{O} 3$ can improve the physicochemical (colloidal) properties of the growth medium, specifically a mineral soil. However, manure and plantation were also able to further enhance such properties. Such new findings and contributions can be useful for the preparation of growth media, which can significantly increase the growth of horticultural crops in controlled conditions. It is a safe and promising method, which can make a big difference in the properties of the growth medium, with affordable expenses, and is recommendable from health and environmental perspectives.

\subsection{Analysis of variance}

The results indicated that the experimental treatments were non-significant on soil $\mathrm{pH}$ meaning that other factors rather than $\mathrm{O} 3$, manure, plantation affect soil $\mathrm{pH}$ or a longer time may be required. However, soil salinity was significantly decreased by the experimental treatments and their interactions indicating that the solubility of ions such as sodium $\left(\mathrm{Na}^{+}\right)$, chloride $(\mathrm{Cl}-)$, calcium $\left(\mathrm{Ca}^{2+}\right)$, and magnesium $\left(\mathrm{Mg}^{2+}\right)$ is affected by $\mathrm{O} 3$ and manure. Additionally, because soil CEC was significantly increased by the experimental treatments, the higher absorption of salt ions on the soil colloids can decrease their solubility in the soil solution and hence decreases soil EC. This can also be due to the higher availability of SOC by $\mathrm{O} 3$, which was also intensified in the presence of manure and plant roots. According to the results under non-planting conditions, just the Oz3 and Oz4 treatments significantly decreased soil salinity; however, in the presence of plant in the soil, the Oz2 treatment was also able to significantly decrease soil salinity [30]. The higher production of $\mathrm{CaCO}_{3}$ by $\mathrm{O} 3$ can be due to higher production of $\mathrm{CO}_{2}$, respiration of plant roots, and manure mineralization, which in combination with $\mathrm{CaO}$ can produce $\mathrm{CaCO}_{3}$.

\subsection{SAW}

The experimental treatments significantly increased SAW. The higher mineralization of soil organic matter by ozone, and higher root growth (rhizosphere activities) in the presence of manure are the reasons for the improved structure of the soil and hence increased SAW. Treating soil with ozone improves the incorporation of organic matter, produced by the plant roots (organic acids), into the structure of the soil, and hence increases SAW. Higher micropores in organic matter, compared with mineral soil, hold higher amounts of water for plant use $[9,10]$.

\section{$4.3 \mathrm{pH}$}

The $\mathrm{pH}$ of the soil is a characteristic, which under some conditions, such as the present research, can be subject to change in a longer period. This is interesting because an oxidizing molecule such as ozone can alter $\mathrm{pH}$; however, the important reason for the non-significant changes of soil $\mathrm{pH}$ in the presented experiment can be due to soil bufferic capacity, which increases in the presence of plant and manure. This can be a favorable characteristic of ozone and manure, for plant growth, because $\mathrm{pH}$ fluctuations may not positively affect plant growth $[33,45]$.

\subsection{Salinity}

The main reason for the reduction of soil salinity by ozone, plant, and manure can be the increased amount of organic matter. Previous research has indicated one of the methods, which efficiently decreases soil salinity, is the use of organic fertilization. Accordingly, Khaleda et al. [22] illustrated the molecular mechanisms by humic acid, which may decrease the negative effects of salinity on the growth of Arabidopsis taliana seedlings. They suggested the possible roles of a high-affinity $\mathrm{K}+$ transporter (HKT1), which can regulate the movement of sodium in plant. Humic acid was able to alleviate the negative effects of salt stress on root growth by the following: (1) regulating the activity of HKT1, (2) blocking the degradation of HKT1, (3) the enhanced distribution of $\mathrm{Na}+$ to the elongation zone, and (4) the reabsorption of $\mathrm{Na}+$ by the cells of xylem and parenchyma. Accordingly, this can also be the reason for the increased soil salinity, when plant is not present. It is because the salt ions are not absorbed by plant, and as a result, their concentration increases in the soil solution. Peykanpour et al. [39] found O3 can reduce the unfavorable effects of salinity on the growth of cucumber. O3, as an oxidizing molecule, can increase the mineralization of soil organic matter, and increase the availability of functional groups, which absorb higher salt ions from the soil solution and decrease soil salinity.

\subsection{SOC}

The important effect of $\mathrm{O} 3$ on SOC is through the oxidation process $[29,41]$ affecting the properties of soil colloids and the subsequent absorption or release of the elements by the soil colloids (the significant increase of soil CEC by the experimental treatments). According to our results, soil physical properties including SAW, aggregates, and porosity are also affected by $\mathrm{O} 3$, manure, and plantation, affecting the absorption, release, and movement of elements in the soil [7]. Manure can improve the colloidal properties of the soil, because it acts as an organic phase [45]. Ozone not 
only increases the rate of chemical oxidation in the soil, by enhancing oxygen $\left(\mathrm{O}_{2}\right)$ concentration [51], it can also accelerate the rate of biochemical oxidation by increasing the respiration of plants and soil organisms.

The results indicated that $\mathrm{O} 3$ decreased SOC, which is due to the higher $\mathrm{O}_{2}$ in the soil, significantly increasing the chemical and biochemical oxidation of SOC [24]. However, plant presence increased SOC, which is mainly due to the biological activities of plant roots and their production of different organic products, increasing the solubility of nutrients and the production of microbial biomass.

\subsection{Plant presence}

Plant presence in the soil can significantly affect soil physicochemical and biological properties $[7,17,18]$. However, in the case of irrigating plant with $\mathrm{O} 3$, due to higher $\mathrm{O} 2$ concentration, plant presence may affect soil physicochemical and biological properties according to the following. Higher $\mathrm{O}_{2}$ concertation increases plant growth including plant roots, which can (1) bind the soil particles and enhance soil structure, (2) release different products including organic acids and increase the solubility of different nutrients for plant and microbial use, and (3) increase soil biological activities including their interactions with the host plants, enhancing nutrient availability, biological fixation of nutrients, controlling pathogens, and alleviating stress [26].

\section{7 $\mathrm{CaCO}_{3}$}

Although the effects of the experimental treatments were not significant on soil $\mathrm{pH}$, their significant effects on soil $\mathrm{CaCO}_{3}$ indicate that if the experimental treatments are tested in a longer time and a large area, it would be possible to adjust soil $\mathrm{pH}$ to the favorite value. Increasing soil $\mathrm{CaCO}_{3}$ by the experimental treatments can be due to the enhanced colloidal properties of the soil such as the availably of SOC and nutrients and the improved structure of the soil such as the stability of aggregates. Increasing ozone concentration increased $\mathrm{CaCO}_{3}$, which can be due to a more favorite soil medium by affecting soil physical, chemical, and biological properties [21, 31].

Increasing $\mathrm{CaCO}_{3}$ in non-planted soil by $\mathrm{O} 3$ can be due to the increase of $\mathrm{O}_{2}$ concentration by $\mathrm{O} 3$, which may provide more oxygen for the biological activities of soil microbes. Accordingly, more $\mathrm{CO}_{2}$ is released, which react with $\mathrm{CaO}$, resulting in the subsequent formation of $\mathrm{CaCO}_{3}$. However, when planted, soil $\mathrm{CaCO}_{3}$ decreased, which can be due to the production of acidic compounds by plant roots, catalyzing $\mathrm{CaCO}_{3}$ to $\mathrm{CaO}$ and $\mathrm{CO}_{2}$, subsequently emitted from the soil [31].

\subsection{MWD and GWD}

The experimental treatments significantly increased the properties of soil aggregates including MWD and GWD as well as soil porosity. Such effects can be due to improving colloidal properties, by the increased amount of soil organic matter and CEC, affecting the binding of soil particles and the formation of soil aggregates [20]. The size of soil porosity was a determining factor on the experimental parameters, as for example, in the size of $>10 \mu \mathrm{m}$, they were more significantly affected by the experimental treatments.

The results by Zhu et al. [53] indicated that organic fertilization significantly increased the stability of soil aggregates by increasing MWD and GWD. Similarly, Cao et al. [5] determined how carbon cycle may be affected by different parameters including SOC and the stability of soil aggregates. They found that SOC significantly increased the stability indexes of soil aggregates, which collectively increased the aboveground biomass. Accordingly, precipitation was the most important factor, significantly affecting SOC and the stability of soil aggregates. Zhang et al. [52] found that the use of biochar as a source of organic fertilization can enhance soil properties in a 6-year rotation of rice-wheat cropping. Accordingly, among the other effects of biochar on yield production, the increased sequestration of carbon [46], which subsequently increased the stability of the soil aggregates, also considerably increased rice and wheat yield.

The use of O3 significantly improved soil physical properties including SAW, and soil aggregate stability and porosity. Interestingly, the single use of $\mathrm{O} 3$ or in combination with manure, significantly decreased soil salinity. The experimental treatments also significantly increased the colloidal properties of the soil such as SOC and CEC. Accordingly, the improvement of soil physicochemical properties by $\mathrm{O} 3$ may significantly enhance the production of horticultural crops.

Another important aspect of irrigating plant with O3, investigated in our just published research [47], is the alteration of plant antioxidant activities. It can interestingly improve plant growth and fruit production under different circumstances including stress conditions and post-harvest during the storage, which is due to the activation of antioxidant pathways [25]. For example, Goffi et al. [15] found ozone can improve the antioxidant activity of 'Soreli'kiwifruit and increase its storability. It is because one of the important reasons for fruit senescence is the production of reactive oxygen species and oxidative stress.

\section{Conclusion and future directions}

The use of modern techniques, including ozonated water (O3), may be a promising approach for the higher and safer production of agricultural and horticultural crops. However, 
the subsequences of such a method on the growth medium properties demand more investigation. In this research, the physicochemical (colloidal) properties of the soil affected by $\mathrm{O} 3$, manure, and plantation presence were examined. The results indicated that the single and the combined use of the experimental treatments significantly enhanced soil physical properties, including soil available water, aggregate stability and soil porosity, and chemical properties including salinity, organic carbon, $\mathrm{CaCO}_{3}$, and cation exchange capacity. Interestingly, decreased soil salinity, increased organic carbon (in planted soil), and increased cation exchange capacity are among the most important effects of the experimental treatments on soil chemical (colloidal) properties. Although $\mathrm{O} 3$ by itself proved to be an effective treatment significantly enhancing soil physicochemical properties, its combination with manure and plant presence intensified $\mathrm{O} 3$ positive effects. It is safe and economic. It is possible to improve plant growth and yield production in a growth medium using the treatments tested in this research; however, more research is required to investigate plant growth under other circumstances including stress conditions. The tested method is a safe and economic method, and can be used for the treatment of irrigation water for increasing the yield of agricultural and horticultural crops. Future research may also investigate strategies, which may increase the efficiency of water ozonation for the improvement of growth medium properties with environmental and economic benefits.

Acknowledgements The authors would like to thank very much, the international publisher, AbtinBerkeh Scientific Ltd. Company (https:// AbtinBerkeh.com), Isfahan, Iran, for editing the manuscript, and revising it according to the journal format

\section{Declarations}

Competing interests The authors declare no competing interests.

\section{References}

1. Alavi, S.A., Ghehsareh, A.M., Soleymani, A., Panahpour, E., Mozafari, M., 2020. Pepermint (Mentha piperita L.) growth and biochemical properties affected by magnetized saline water. Ecotoxicology and Environmental Safety 201, 110775.

2. Alavi SA, Ghehsareh AM, Soleymani A, Panahpour E (2021) Enhanced nutrient uptake in salt-stressed Mentha piperita using magnetically treated water. Protoplasma 258:403-414

3. Ali E, Ekwue EI, Bridge J, Birch R (2013) A three-stack mechanical sieve shaker for determining aggregate size distribution of soils. West Indian Journal of Engineering 35:36-44

4. Asghar A, Raman AAA, Daud WMAW (2015) Advanced oxidation processes for in-situ production of hydrogen peroxide/ hydroxyl radical for textile wastewater treatment: a review. J Clean Prod 87:826-838

5. Cao ZY, Wang Y, Li J, Zhang JJ, He NP (2016) Soil organic carbon contents, aggregate stability, and humic acid composition in different alpine grasslands in Qinghai-Tibet Plateau. J Mt Sci 13:2015-2027

6. Cassel DK, Nielsen DR (1986) Field capacity and available water capacity. Methods of Soil Analysis. Part 1 Physical and Mineralogical Methods 5:901-926

7. Chen W, Zhang L, Li X, Ye R, Li Q, Zhu J, Fang N, Wang L, Wu Z, Horwath WR (2015) Elevated ozone increases nitrifying and denitrifying enzyme activities in the rhizosphere of wheat after 5 years of fumigation. Plant Soil 392:279-288

8. Chen T, Delgado AG, Yavuz BM, Proctor AJ, Maldonado J, Zuo Y, Westerhoff P, Krajmalnik-Brown R, Rittmann BE (2016) Ozone enhances biodegradability of heavy hydrocarbons in soil. J Environ Eng Sci 11:7-17

9. Chen Z, Li M, Wen Q, Ren N (2017) Evolution of molecular weight and fluorescence of effluent organic matter (EfOM) during oxidation processes revealed by advanced spectrographic and chromatographic tools. Water Res 124:566-575

10. Chen X, Jiang N, Condron LM, Dunfield KE, Chen Z, Wang J, Chen L (2019) Soil alkaline phosphatase activity and bacterial phoD gene abundance and diversity under long-term nitrogen and manure inputs. Geoderma 349:36-44

11. Choi H, Kim YY, Lim H, Cho J, Kang JW, Kim KS (2001) Oxidation of polycyclic aromatic hydrocarbons by ozone in the presence of sand. Water Sci Technol 43:349-356

12. Ding W, Jin W, Cao S, Zhou X, Wang C, Jiang Q, Huang H, Tu R, Han SF, Wang Q (2019) Ozone disinfection of chlorine-resistant bacteria in drinking water. Water Res 160:339-349

13. Dove, B., Gereer, D., McDavid, D., Wilcox, D. 2002. UTHSCSA Image 3.0 Software. The University of Texas Health Science Center, San Antonio, 100p.

14. Gee, G.W., Bauder. J.W., 1986. Particle-size analysis. In: Klute, A. (Ed.), Methods of Soil Analysis, Part 1, second ed. Agronomy Monograph, vol. 9. ASA and SSSA, Madison, WI, pp. 383-411.

15. Goffi V, Magri A, Botondi R, Petriccione M (2020) Response of antioxidant system to postharvest ozone treatment in 'Soreli'kiwifruit. J Sci Food Agric 100:961-968

16. Graham T, Zhang P, Woyzbun E, Dixon M (2011) Response of hydroponic tomato to daily applications of aqueous ozone via drip irrigation. Sci Hortic 129:464-471

17. Hu E, Yuan Z, Zhang H, Zhang W, Wang X, Jones SB, Wang $\mathrm{N}$ (2018) Impact of elevated tropospheric ozone on soil C, N and microbial dynamics of winter wheat. Agr Ecosyst Environ 253:166-176

18. Huang YZ, Zhong M (2015) Influence of elevated ozone concentration on methanotrophic bacterial communities in soil under field condition. Atmos Environ 108:59-66

19. Ikhlaq A, Brown DR, Kasprzyk-Hordern B (2013) Mechanisms of catalytic ozonation: an investigation into superoxide ion radical and hydrogen peroxide formation during catalytic ozonation on alumina and zeolites in water. Appl Catal B 129:437-449

20. Kaiser M, Kleber M, Berhe AA (2015) How air-drying and rewetting modify soil organic matter characteristics: an assessment to improve data interpretation and inference. Soil Biol Biochem 80:324-340

21. Kamal MZU, Yamaguchi M, Kinose Y, Izuta T (2019) Mitigation mechanism of ozone-induced reduction in net photosynthesis of Bangladeshi wheat under soil salinity stress. Photosynthetica 57:1025-1034

22. Khaleda L, Park HJ, Yun DJ, Jeon JR, Kim MG, Cha JY, Kim WY (2017) Humic acid confers high-affinity $\mathrm{K}^{+}$transporter 1-mediated salinity stress tolerance in Arabidopsis. Mol Cells 40:966

23. Klute, A.1986. Methods of soil analysis part 1. Physical and mineralogical method. Soil Science Society of America, Madison WIS. USA. P 1189.

24. Lehmann J, Kleber M (2015) The contentious nature of soil organic matter. Nature 528:60 
25. Miller FA, Silva CL, Brandão TR (2013) A review on ozone-based treatments for fruit and vegetables preservation. Food Engineering Reviews 5:77-106

26. Miransari M (2011) Interactions between arbuscular mycorrhizal fungi and soil bacteria. Appl Microbiol Biotechnol 89:917-930

27. Miransari M (2011) Soil microbes and plant fertilization. Appl Microbiol Biotechnol 92:875-885

28. Miransari M, Bahrami HA, Rejali F, Malakouti MJ (2008) Using arbuscular mycorrhiza to alleviate the stress of soil compaction on wheat (Triticum aestivum L.) growth. Soil Biol Biochem 40:1197-1206

29. Moreira FC, Boaventura RA, Brillas E, Vilar VJ (2017) Electrochemical advanced oxidation processes: a review on their application to synthetic and real wastewaters. Appl Catal B 202:217-261

30. Najarian M, Mohammadi-Ghehsareh A, Fallahzade J, Peykanpour E (2018) Responses of cucumber (Cucumis sativus L.) to ozonated water under varying drought stress intensities. J Plant Nutr 41:1-9

31. Nalan K, Ekberli I (2020) The relation between yield indices of maize plant and soil physicochemical characteristics. Eurasian Journal of Soil Science 9:52-59

32. Nelson DW, Sommers LE (1982) Total carbon, organic carbon, and organic matter. In: Page AL, Miller RH, Keeney DR (eds) Methods of Soil Analysis, Part 2, 2nd edn. American Society of Agronomy, Madison, WI, pp 539-573

33. Ning, Q., Chen, L., Jia, Z., Zhang, C., Ma, D., Li, F., Zhang, J., Li, D., Han, X., Cai, Z., Huang, S., 2020. Multiple long-term observations reveal a strategy for soil $\mathrm{pH}$-dependent fertilization and fungal communities in support of agricultural production. Agriculture, Ecosystems \& Environment 293, 106837.

34. Pagliai M (1988) Soil porosity aspects International Agrophysics 4:215-232

35. Pandiselvam R, Manikantan MR, Divya V, Ashokkumar C, Kaavya R, Kothakota A, Ramesh SV (2019) Ozone: an advanced oxidation technology for starch modification. Ozone Science \& Engineering 41:491-507

36. Pandiselvam R, Subhashini S, BanuuPriya EP, Kothakota A, Ramesh SV, Shahir S (2019) Ozone based food preservation: a promising green technology for enhanced food safety. Ozone. Science \& Engineering 41:17-34

37. Pandiselvam R, Mayookha VP, Kothakota A, Sharmila L, Ramesh SV, Bharathi CP, Gomathy K, Srikanth V (2020) Impact of ozone treatment on seed germination-a systematic review. Ozone. Science \& Engineering 42:331-346

38. Peng YANG, Guo YZ, Ling QIU (2018) Effects of ozone-treated domestic sludge on hydroponic lettuce growth and nutrition. $\mathrm{J}$ Integr Agric 17:593-602

39. Peykanpour E, Mohammadi Ghehsareh A, Fallahzade J, Najarian M (2016) Interactive effects of salinity and ozonated water on yield components of cucumber. Plant Soil Environ 62:361-366

40. Psaltou S, Kaprara E, Mitrakas M, Zouboulis A (2020) cAlcite mineral catalyst capable of enhancing micropollutant degradation during the ozonation process at $\mathrm{pH} 7$. Environmental Sciences Proceedings 2:26
41. Qi F, Xu B, Chu W (2015) Heterogeneous catalytic ozonation of phenacetin in water using magnetic spinel ferrite as catalyst: comparison of surface property and efficiency. J Mol Catal A: Chem 396:164-173

42. Qu L, Huang Y, Ma K, Zhang Y, Biere A (2016) Effects of plant cover on properties of rhizosphere and inter-plant soil in a semiarid valley, SW China. Soil Biol Biochem 94:1-9

43. Rhoades JD (1982) Soluble salts. In: Page AL, Miller RH, Keeney DR (eds) Methods of Soil Analysis, Part2, 2nd edn. American Society of Agronomy, Madison, WI, pp 167-178

44. Rhoads JD (1986) Cation exchange capacity. In: Page A.C. (Ed.). Methods of Soil Analysis, Part 2. American Society of Agronomy 9:149-158

45. Shahabifar J, Panahpour E, Moshiri F, Gholami A, Mostashari M (2019) The quantity/intensity relation is affected by chemical and organic P fertilization in calcareous soils. Ecotoxicol Environ Saf 172:144-151

46. Shokuhifar, Y., Ghahsareh, A.M., Shahbazi, K., Tehrani, M.M., Besharati, H., 2021. Biochar and wheat straw affecting soil chemistry and microbial biomass carbon countrywide. Biomass Conversion and Biorefinery in press.

47. Tahamolkonan, M., Mohammadi Ghahsareh, A., Kalbasi Ashtari, M., Honarjoo, N. 2021. Tomato (Solanum lycopersicum) growth and fruit quality affected by organic fertilization and ozonated water. Protoplasma in press.

48. Tizaoui C (2020) Ozone: a potential oxidant for COVID-19 virus (SARS-CoV-2). Ozone Science \& Engineering 42:378-385

49. Walkley A, Black IA (1934) An examination of the Degtjareff method for determining soil organic matter, and a proposed modification of the chromic acid titration method. Soil Sci 37:29-38

50. Wei C, Zhang F, Hu Y, Feng C, Wu H (2017) Ozonation in water treatment: the generation, basic properties of ozone and its practical application. Rev Chem Eng 33:49-89

51. Xu Y, Lin Z, Zheng Y, Dacquin JP, Royer S, Zhang H (2019) Mechanism and kinetics of catalytic ozonation for elimination of organic compounds with spinel-type $\mathrm{CuAl} 2 \mathrm{O} 4$ and its precursor. Sci Total Environ 651:2585-2596

52. Zhang, Q., Song, Y., Wu, Z., Yan, X., Gunina, A., Kuzyakov, Y., Xiong, Z., 2020. Effects of six-year biochar amendment on soil aggregation, crop growth, and nitrogen and phosphorus use efficiencies in a rice-wheat rotation. Journal of Cleaner Production $242,118435$.

53. Zhu F, Li Y, Xue S, Hartley W, Wu H (2016) Effects of ironaluminium oxides and organic carbon on aggregate stability of bauxite residues. Environ Sci Pollut Res 23:9073-9081

Publisher's note Springer Nature remains neutral with regard to jurisdictional claims in published maps and institutional affiliations. 